\title{
Wydatki na leczenie raka piersi w Polsce
}

\author{
Adam Kozierkiewicz ${ }^{1}$, Andrzej Śliwczyński², Marcin Pakulski², Jacek Jassem³
}

\begin{abstract}
Wstęp. Rak piersi jest jednym z najważniejszych problemów onkologicznych, a jednocześnie jest chorobą coraz częściej uleczalną. System zwalczania raka piersi powinien posiadać odpowiednią infrastrukturę oraz zapewniać skuteczne klinicznie i uzasadnione ekonomicznie metody leczenia. W tej sytuacji istotna jest wiedza na temat wydatków (z punktu widzenia płatnika), a także kosztów (z punktu widzenia wykonawcy usług) leczenia, tak aby decyzje o nakładach na leczenie raka piersi były obarczone najmniejszym możliwym ryzykiem. O ile w prowadzeniu leczenia zaleca się stosowanie metod opartych na dowodach o charakterze klinicznym (evidence based medicine), tak zarządzanie powinno być oparte na dowodach o charakterze ekonomicznym (evidence based management). Niniejsza analiza jest przyczynkiem do dyskusji na temat właściwego zarządzania finansami w leczeniu chorych na raka piersi. Materiał i metody. W pracy wykorzystano dane NFZ dostępne w systemie pod nazwą: Rejestr Leczenia Chorób. Analizie poddano dane dotyczące około 104 tys. chorych leczonych w Polsce z powodu raka piersi w latach 2004-2010, to jest wszystkich chorych zidentyfikowanych jako potwierdzone przypadki raka piersi finansowane w tym okresie przez NFZ. Wykonano analizę wydatków na leczenie poszczególnych chorych, obejmującą wydatki ponoszone od rozpoznania do wyleczenia (lub zgonu). Analiza obejmuje wydatki NFZ, zatem jest analizą kosztów bezpośrednich, nie uwzględniającą wydatków ponoszonych przez chorych.

Wyniki. Wydatki związane z leczeniem chorych na raka piersi rosły w latach 2004-2010 w tempie przekraczającym tempo inflacji konsumenckiej i w roku 2010 osiągnęły ok. 500 mln PLN. Wydatki na osobę w tym roku wynosiły średnio 32 tys. PLN, przy znaczących różnicach pomiędzy poszczególnymi województwami. Wydatki na osobę zdecydowanie obniżały się z wiekiem — z ok. 67 tys. PLN u chorych 30-letnich do ok. 20 tys. u osób ponad 80-letnich. Wydatki na osoby, które przebyły badanie przesiewowe w kierunku raka piersi, były o około 8-15\% niższe niż u pozostałych chorych. Wnioski. Przedstawione dane obrazują skalę obciążenia finansowego wynikającego z leczenia raka piersi w Polsce. Dzięki danym gromadzonym w NFZ możliwe jest wyliczenie całkowitych wydatków oraz wykazanie różnic w wydatkach pomiędzy różnymi grupami chorych różniących się miejscem zamieszkania, wiekiem, datą rozpoczęcia leczenia czy uczestnictwem w badaniach przesiewowych. Powyższe dane pozwalają na bardziej świadome i bezpieczne projektowanie zmian i modyfikacji w systemie zwalczania raka piersi.
\end{abstract}

\section{Breast cancer treatment expenditures in Poland}

Introduction. Breast cancer is one of the major problems of cancer, althought it is increasingly a treatable disease. The fight against breast cancer should have an appropriate infrastructure and provide a clinically effective and cost effective method of treatment. In this case, the knowledge on expenditures is essential (from the perspective of the payer) and also costs of treatment (in terms of contractor services), so that decisions about expenditures on treating breast cancer have been burdened with the least possible risk. Whereas treatment decisions should be based on clinical evidence (evidence-based medicine), management should be based on evidence of an economic nature (evidence-based management). The current analysis contributes to the discussion on proper financial management in the treatment of breast cancer.

Materials and methods. This analysis was based on the National Health Fund (NHF) data, available in the Register of Diseases' Treatment system. We analyzed data on about 104,000 patients treated in Poland for breast cancer in

${ }^{1}$ Europejski Bank Inwestycyjny, JASPERS*

${ }^{2}$ Narodowy Fundusz Zdrowia

${ }^{3}$ Katedra i Klinika Onkologii i Radioterapii, Gdański Uniwersytet Medyczny

${ }^{*}$ Wyrażone opinie są opiniami autora i nie muszą odzwierciedlać stanowiska EIB 
the years 2004-2010. That is, on all the patients identified as "confirmed" in the NHF system during this period. The entire expenditure on therapy of particular patients have been counted, including expenditure from the beginning of therapy to cure (or death). This analysis includes only NHF expenditure (the direct costs), and does not include costs incurred by patients.

Results. Expenditure related to breast cancer treatment increased between 2004 and 2010 at a rate exceeding the rate of consumer inflation, and in 2010 reached about 500 million PLN. In 2010 expenditure per person averaged 32 thousand PLN, with significant differences between individual regions. Expenditure per capita decreased strongly with age - from about 67 thousand PLN in patients aged 30 years, to about 20 thousand PLN in those over 80 years old. Expenditure on people who have undergone a screening mammography were about 8-15\% lower than in other patients.

Conclusions. Our data illustrate the scale of the financial burden of treatment of breast cancer in Poland. Using data accumulated in the NHF it is possible to calculate the total expenditure, and to demonstrate the differences in spending between groups of patients differing in place of residence, age, date of commencement of treatment, or participation in screening. These data allow for more informed and safe designing of changes and modifications in the system of breast cancer management.

NOWOTWORY Journal of Oncology 2013; 63, 3: 217-226

Słowa kluczowe: rak piersi, wydatki na leczenie, koszty leczenia

Key words: breast cancer, health care expenditure, treatment costs

\section{Wstęp}

Wydatki na opiekę zdrowotną w większości krajów świata stanowią ważny element dyskusji publicznej dotyczącej systemu ochrony zdrowia. Wydatki te często omawia się w kontekście roli państwa i instytucji publicznych w procesie ochrony i zachowania zdrowia [1]. Szeroko dyskutowane są zagadnienia dotyczące natury tych wydatków i ich związku z sytuacją ekonomiczną danego kraju [2]. Wobec problemów finansowych, które ujawniły się w wielu krajach w ostatnich latach, szczególnej wagi nabiera związek pomiędzy wydatkami a osiąganymi dzięki nim efektami [3]. Zagadnienie to było także przedmiotem raportu Biała Księga na temat zwalczania raka piersi [4], opracowanego w roku 2011 pod patronatem Polskiego Towarzystwa Onkologicznego. Raport koncentrował się jednak na ogólnych, siłą rzeczy powierzchownych parametrach poszczególnych krajów (wysokość wydatków na ochronę zdrowia ogółem, na osobę na rok, oraz wskaźniki 5-letniego przeżycia w wybranych nowotworach). Z analizy tej wynikało m.in., że istnieje związek pomiędzy wysokością nakładów na ochronę zdrowia a wskaźnikami przeżycia analizowanych nowotworów. Co prawda, nie można było wykazać bezpośredniego związku przyczynowo-skutkowego, jednak współczynnik korelacji pomiędzy tymi zmiennymi wskazywał na istotność statystyczną tej obserwacji (w 1999 i 2006 roku dla raka piersi - odpowiednio 0,71 i 0,75, a dla raka jelita grubego - 0,68 i 0,80). Jednocześnie można było zaobserwować, że wśród porównywanych krajów są takie, w których przy podobnych nakładach na ochronę zdrowia uzyskuje się istotnie różne wskaźniki przeżycia. Taka sytuacja występowała m.in. między Wielką Brytanią a Finlandią, krajami o podobnych nakładach (ok. 3,8 tys. USD/rok/osobę) i dużych różnicach we wskaźnikach przeżycia w raku piersi (odpowiednio 79\% do $87 \%$ ). W związku z tymi obserwacjami autorzy raportu uznali, że celowe jest przeprowadzenie podobnej, ale bardziej szczegółowej analizy, aby dokonać oceny związku pomiędzy wydatkami na ochronę zdrowia a jej skutecznością. Niniejsza praca jest pierwszym krokiem w tym kierunku.

Niniejsze opracowanie stanowi analizę porównawczą wydatków na leczenie chorych na raka piersi, ponoszonych przez Narodowy Fundusz Zdrowia (NFZ) w latach 2004-2010 w czterech wymiarach porównań:

- pomiędzy województwami,

- pomiędzy grupami wiekowymi chorych,

- pomiędzy okresami (latami) rozpoczęcia leczenia,

- pomiędzy osobami objętymi i nieobjętymi mammograficznymi badaniami przesiewowymi.

Badanie przeprowadzono z wykorzystaniem danych chorych, które w latach 2004-2010 rozpoczęły leczenie z powodu raka piersi (C50), finansowane przez NFZ. W bazie danych NFZ (charakterystyka poniżej) chore te mają status "potwierdzonych" przypadków raka piersi. Z puli tej wyłączono chore, u których prowadzono badania diagnostyczne w kierunku raka piersi i w tym celu wykonano u nich pojedyncze usługi, lecz nie podjęto interwencji charakterystycznych dla leczenia raka, tj. zabiegu chirurgicznego, chemio-, radioterapii czy opieki paliatywnej. Ogólna liczba chorych poddanych analizie wynosiła około 104 000, przeciętnie ok. 15000 chorych w każdym z analizowanych roczników. Analizę wykonano wyłącznie dla kobiet, głównie z tego powodu, że wśród chorujących na raka piersi stanowią one dominującą większość (150:1 w stosunku do mężczyzn). 
Wydatki ujęte w analizie miały charakter wydatków bezpośrednich (direct costs), ponieważ dotyczyły świadczeń medycznych wykonanych na rzecz chorych. Dane nie obejmowały wszystkich wydatków zaliczanych zwykle do tej kategorii, w szczególności wydatków ponoszonych prywatnie. Ujęte w analizie wydatki na świadczenia ponoszone były $w$ roku rozpoczęcia leczenia oraz w kolejnych latach, do końca 2011 roku (data pobrania danych). Obserwacja wydatków miała zatem charakter ciągły (longitudinalny), obejmujący okres od pierwszego świadczenia związanego z danym nowotworem do chwili pobrania zbiorów danych.

Granice możliwości analitycznych wyznaczał zakres danych dostępnych w bazach danych NFZ. Najważniejszym ograniczeniem był brak zróżnicowania chorych według stadium klinicznego nowotworu, ponieważ z praktyki klinicznej oraz wielu doniesień wynika, że koszty leczenia zależą w znacznym stopniu od zaawansowania nowotworu [5-7]. Na obecnym etapie nie było zatem możliwości określenia wpływu tej cechy na koszty leczenia. W związku z tym konieczne było poczynienie założenia, że rozkład częstości występowania chorych na raka w poszczególnych stadiach może być jednym z czynników determinujących różnice $w$ wydatkach na leczenie w poszczególnych województwach, grupach wiekowych lub latach rozpoznania. Alternatywnie można jednak założyć, że w całej populacji leczonych odsetek osób w poszczególnych stadiach klinicznych jest podobny i stały w czasie. W tym drugim przypadku ewentualne różnice $w$ wydatkach oddają raczej różnice w schematach postępowania klinicznego, aniżeli różnice w stanie klinicznym chorych.

Wyniki analiz zaprezentowano z wykorzystaniem oprogramowania o nazwie InstantAtlas ${ }^{\circledR}$, firmy Geowise Ltd. Materiał analityczny zawierający wszystkie tabele, mapy oraz wykresy został umieszczony na stronie Polskiego Towarzystwa Onkologicznego (www.pto.med.pl).

\section{Materiał i metody Charakterystyka źródła danych}

Świadczenia zdrowotne są w Polsce finansowane przez NFZ na podstawie Ustawy o świadczeniach zdrowotnych finansowanych ze środków publicznych [8] oraz wynikających z niej rozporządzeń Ministra Zdrowia [9]. W jednym z tych rozporządzeń Minister Zdrowia określił zakres danych gromadzonych przez świadczeniodawców i przekazywanych NFZ [10]. Z punktu widzenia niniejszej analizy najważniejszymi elementami sprawozdawanych danych są identyfikatory chorego (w tym PESEL), rozpoznanie kliniczne oznaczone kodem Międzynarodowej Statystycznej Klasyfikacji Chorób i Problemów Zdrowotnych [11] oraz kod i nazwa świadczenia, w nomenklaturze ubezpieczeniowej zwanego produktem. W przypadku chorych uzyskujących świadczenia z danego powodu rozpoznanie może występować w zestawie danych sprawozdawczych jako rozpoznanie główne lub współistniejące. Obecne rozporządzenie obowiązuje od 2006 roku, jednak we wcześniejszych latach obowiązywały podobne regulacje, a pierwsze rozporządzenie dotyczące tego zagadnienia zostało wydane w roku 1999, czyli na początku działania w Polsce Kas Chorych. Przetwarzanie danych odbywa się z wykorzystaniem informatycznego systemu, pierwotnie obsługiwanego przez dwie spółki informatyczne. Od 2004 roku następuje stopniowa integracja tych dwóch systemów, ujednolicenie sposobu gromadzenia, a także stopniowa poprawa jakości i kompletności danych.

W celu umożliwienia obsługi analiz danych związanych z onkologią, w systemie informatycznym Centrali Narodowego Funduszu Zdrowia został stworzony moduł pod nazwą „Rejestr Leczenia Chorób” (RLC). Moduł oparty na technologii webowej powstał w 2009 roku i pozwala na ekstrakcję oraz analizę danych dla wszystkich rozpoznań onkologicznych (ICD-10 „C00-D09”). Moduł udostępnia dane gromadzone przez NFZ w cyklach miesięcznych oraz archiwalne dane, w tym dane z Kas Chorych od 2002 roku. Wymienione zbiory danych, pierwotnie umieszczone w różnych miejscach systemu informatycznego NFZ, zgromadzono na jednym serwerze, w strukturze typu hurtowni danych. Założono dostępność do modułu wyszukiwania z dowolnego miejsca za pośrednictwem przeglądarki internetowej, poprzez uwierzytelnione logowanie oraz bezpieczne łącze.

System RLC wyposażony jest w interfejs pozwalający na formułowanie zapytania do bazy danych epizodów leczenia. Liczba parametrów, jakie można określić, jest ograniczona, jednak pozwala na przeprowadzenie wielu rodzajów analiz. Dla celów niniejszej analizy korzystano z jednej z części interfejsu, zatytułowanej „Analiza nowotworów — podział geograficzny".

W badaniu dokonano wyboru danych o leczeniu chorych, u których po raz pierwszy zarejestrowano świadczenie z kodem C50 w poszczególnych latach z okresu 2004-2010. Ograniczenie roczników do 2010 roku spowodowane było tym, że dane z rocznika 2011 w czasie ich opracowywania (początek 2012) nie były jeszcze kompletne.

\section{Metoda badawcza}

Oznaczenie epizodu korzystania z opieki zdrowotnej kodem C50 jest naturalnym wskazaniem, że u danej osoby rozpoznano raka piersi. Oznaczenie to stawiane może być jednak w przypadku dowolnego świadczenia, od porady ambulatoryjnej w podstawowej opiece zdrowotnej po hospitalizację (zasadniczo dowolnego rodzaju) czy pobyt w zakładzie opiekuńczo-leczniczym. W przypadkach podejrzenia lub niepełnego rozpoznania personel medyczny teoretycznie powinien posłużyć się kodem ICD-10 z zakresu D37-D48 lub np. Z03.1 Obserwacja w kierunku podejrzewanego nowotworu złośliwego. W praktyce jednak trudno się spodziewać takiej jakości kodowania i fakt ten należy uznać za potencjalny czynnik niepewności niniejszej analizy. 
Z tego względu, w celu wyselekcjonowania przypadków osób rzeczywiście leczonych z powodu raka piersi, założono dodatkowe warunki poza kodem rozpoznania C50.W szczególności starano się o wyeliminowanie z badanej populacji osoby, u których na pewnym etapie podejrzewano raka piersi, ale ostatecznie go nie potwierdzono i nie podjęto odpowiednich interwencji medycznych. Warunkami uznania osoby za chorującą (i leczoną) na raka piersi było uzyskanie przez tę osobę co najmniej jednego z następujących świadczeń:

- chemioterapia - kategoria zawierająca 1004 kontraktowane produkty, począwszy od punktów rozliczeniowych poradni chemioterapii po terapie z zastosowaniem poszczególnych substancji;

- radioterapia - kategoria zawierająca 37 kontraktowanych produktów obejmujących punkty rozliczeniowe schematów radioterapii, brachyterapię oraz usługi towarzyszące, takie jak hospitalizacja w trakcie radioterapii;

- leczenie chirurgiczne - kategoria obejmująca 408 kontraktowanych produktów zawierających zabiegi chirurgiczne wykonywane w trybie dziennym i szpitalnym, w tym grupy zabiegowe JGP;

- opieka paliatywna - kategoria obejmująca 31 kontraktowanych produktów, w tym usługi wykonywane w trybie dziennym, szpitalnym, domowym i ambulatoryjnym. Aby dane świadczenie wliczyć do puli świadczeń wykonanych z powodu raka piersi, świadczenie powinno było być sprawozdane w postaci zapisu (rekordu), zawierającego m.in. kod rozpoznania ICD-10: C50 Rak piersi. Założono przy tym, że liczba osób rzeczywiście chorych na raka piersi, które po pojedynczych epizodach kontaktu ze świadczeniodawcami nie uzyskują żadnej z charakterystycznych dla leczenia nowotworów interwencji medycznych, jest na tyle niewielka, że nie wpływa istotnie na wyniki niniejszych analiz ${ }^{1}$.

W wyniku określenia ww. warunków zdefiniowano trzy kategorie chorych:

- kategoria podejrzanych (o raka piersi) - przypadki chorych, którzy w danym okresie uzyskali co najmniej jedno świadczenie oznaczone kodem C50, przy czym nie było to świadczenie o charakterze zabiegowym (chirurgicznym), radioterapii, chemioterapii lub opieki paliatywnej, czyli jedno ze świadczeń charakterystycznych dla terapii nowotworów;

- kategoria potwierdzonych (przypadków raka piersi) - przypadki chorych, którzy w danym okresie uzyskali co najmniej jedno świadczenie oznaczone kodem C50, w tym co najmniej jedno o specyficznym charakterze, tj. o charakterze zabiegowym (chirurgicznym), radioterapii, chemioterapii lub opieki paliatywnej, oznaczone tym samym kodem rozpoznania (tu: $\mathrm{C50}$ );
- ogółem (potwierdzenie i podejrzenie) — suma obu kategorii (zbiorów).

Założono przy tym, że wystąpienie jednego ze świadczeń charakterystycznych dla leczenia nowotworów (np.zabiegu chirurgicznego) oraz rozpoznania C50 (rak piersi) w jednym rekordzie jest tożsame ze stwierdzeniem, że zabieg ten został wykonany z tej, a nie innej przyczyny. Stanowisko takie jest logiczne oraz zgodne z zasadami kodowania określonymi w instrukcjach kodowania klasyfikacji chorób, klasyfikacji procedur medycznych, a także zaleceniach NFZ. Nie można oczywiście wykluczyć, że zdarzają się przypadki, gdzie przeprowadzono zabieg niezwiązany z rakiem piersi, a w polu jednostki chorobowej wpisywany jest kod C50, jednak uznano, że takie przypadki są bardzo rzadkie, tym bardziej, że stopniowo rozwijane narzędzia walidacyjne używane w systemie informatycznym NFZ powinny je wychwytywać i oznaczać jako błędy.

Analizie poddano wydatki Narodowego Funduszu Zdrowia na świadczenia zdrowotne, które zostały zrealizowane dla pacjentów sprawozdanych do Funduszu z rozpoznaniami C50.X (wszystkie rozszerzenia). Do analizy wprowadzono dane pacjentów, dla których w latach 2005-2007 rozpoznania te były wykazywane jako rozpoznania główne (nie wykazywano w tych latach rozpoznań współistniejących), a dla lat 2008-2011, po wprowadzeniu systemu Jednorodnych Grup Pacjentów (JGP), dołączono populację pacjentów, dla których ww. rozpoznania wystąpiły również jako rozpoznania współistniejące.

Przypisanie chorych do województw w niniejszej analizie oparte było na miejscu zamieszkania pacjenta, a nie na miejscu wykonywania świadczeń czy oddziału wojewódzkiego NFZ, który leczenie opłacał. W znacznej mierze miejsce zamieszkania odpowiada oddziałowi wojewódzkiemu, w którym pacjent jest ubezpieczony, choć występują między tymi wielkościami różnice. Ocena tych różnic wykonana na próbie ok. 184 tysięcy przypadków leczonych w całym okresie od 1999 do 2012 roku pozwoliła oszacować, co następuje:

- ok. $17 \%$ wszystkich chorych na raka piersi co najmniej raz skorzystało ze świadczenia z tego powodu poza swoim województwem zamieszkania,

- wydatki poniesione poza miejscem zamieszkania danej osoby stanowiły ok. 9\% całkowitych wydatków związanych z rakiem piersi,

— województwo zamieszkania zmieniło ok. 0,18\% żyjącej obecnie populacji osób kiedykolwiek leczonych z powodu raka piersi.

Podobnie przypisanie wydatków do województw odnosi się do miejsca zamieszkania pacjenta, a nie oddziału ubezpieczenia czy też miejsca ponoszenia wydatków (lokalizacji placówek leczących). W przypadku pacjentów, którzy

${ }^{1}$ Scenariuszami, które przy takim założeniu nie zostały ujęte, jest np. taki, w którym chora, u której rozpoznano raka piersi nie podejmuje żadnego leczenia w tym kierunku i ostatecznie umiera, lub taki, w którym chora zostaje przyjęta do szpitala, gdzie bez podjęcia leczenia chirurgicznego, radiolub chemioterapii, umiera. Wydaje się, że oba scenariusze są bardzo rzadkie, choć powinny być poddane osobnej analizie. 
Tabela I. Liczba chorych na raka piersi rozpoczynających leczenie finansowane przez NFZ w latach 2004-2010 oraz wydatki NFZ na ich leczenie

\begin{tabular}{|c|c|c|c|c|c|c|c|}
\hline & 2004 & 2005 & 2006 & 2007 & 2008 & 2009 & 2010 \\
\hline Liczba chorych & 15514 & 14480 & 13914 & 14726 & 14692 & 14912 & 15002 \\
\hline $\begin{array}{l}\text { Wydatki na leczenie chorych wg roku } \\
\text { rozpoczęcia leczenia (w mln) (podejście } \\
\text { „memoriałowe”) }\end{array}$ & 324,3 & 322,3 & 337,6 & 415,8 & 477,9 & 528,5 & 486,8 \\
\hline $\begin{array}{l}\text { Wydatki na leczenie chorych wg roku } \\
\text { poniesienia wydatków (w mln) (podejście } \\
\text { „kasowe") }\end{array}$ & 196,7 & 270,6 & 300,7 & 354,1 & 525,5 & 726,1 & 797,2 \\
\hline
\end{tabular}

Źródło: dane NFZ

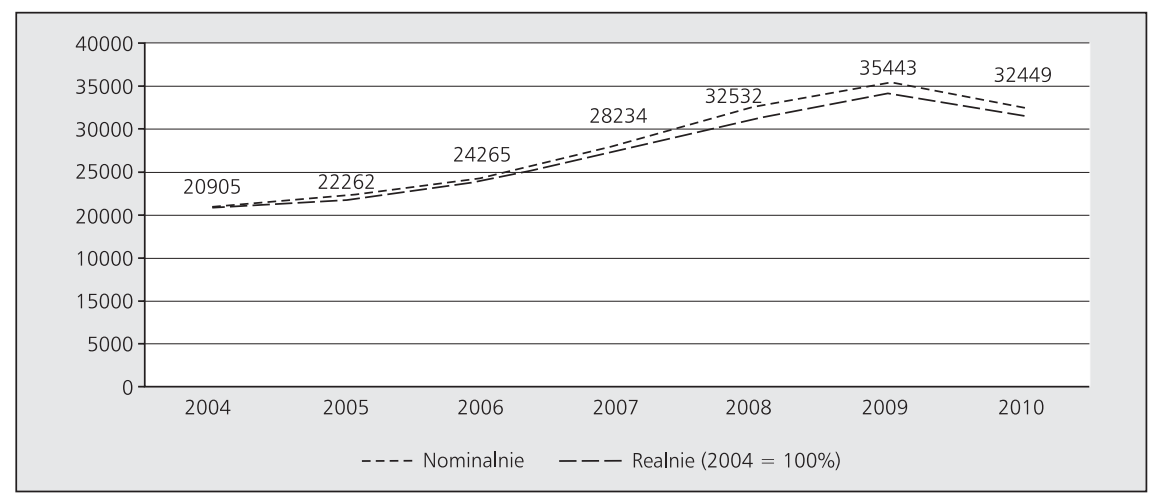

Rycina 1. Średnie wydatki NFZ na leczenie jednej chorej na raka piersi w latach 2004-2010 w wartościach nominalnych oraz realnych (rok odniesienia: 2004). Źródło: obliczenia własne na podstawie danych NFZ i Głównego Urzędu Statystycznego

w międzyczasie zmienili miejsce zamieszkania i zmiana ta została odnotowana w systemie informatycznym NFZ, zmienione zostało także przyporządkowanie do województwa (wzmiankowane 0,18\%). W tej sytuacji, można przypuścić, że pewna liczba chorych oraz wydatków, jakie z nimi są związane, „przemieściła” się między województwami.

\section{Wyniki}

Analizie poddano wydatki dotyczące chorych leczonych w ramach umów NFZ, które rozpoczęły leczenie w jednym z lat 2004-2010. Ich liczba w tych wszystkich latach wynosiła 103240 (tab. I), tj. około 15000 rocznie.

Za cały analizowany okres wydatki NFZ związane z leczeniem raka piersi w latach objętych analizą 2004-2010 (tab. I) wyniosły ok. 2893 mld PLN. W poszczególnych latach następował ich stopniowy wzrost z ok. 324 milionów na osoby rozpoczynające leczenie w roku 2004 do 487 milionów PLN dla tych w roku 2010 (tab. I). Jak wskazano poprzednio, przedstawione wydatki dotyczą świadczeń sprawozdawanych z kodem C50 (rak piersi) i przypisanych do roku, w którym rozpoczęto leczenie, a nie do roku w którym leczenie prowadzono. Zatem jeśli np. nowotwór został rozpoznany w grudniu 2008, a leczenie kontynuowano przez cały rok 2009 i część 2010 r., wydatki na tę chorą zostały przypisane rocznikowi 2008. Jest to zatem specyficzne podejście memoriałowe do kosztów NFZ, przypisujące koszt, z punktu widzenia NFZ, do roku, w którym uruchomiono proces leczenia. Z tego podejścia wynika m.in. różnica z kwotą wydatków na leczenie raka piersi ponoszonych w danym roku (tab. I) (podejście kasowe). Wynika z tego także taka konsekwencja, że w miarę upływu czasu omawiana suma wydatków dla poszczególnych roczników będzie stopniowo, choć lekko wzrastać. Dzieje się tak, ponieważ żyjące osoby dalej korzystają ze świadczeń związanych z rakiem piersi (follow up), choć kwoty wydawane na te świadczenia są już jednostkowo niewielkie.

W zaprezentowanego podejścia wynika także niższa kwota wydatków u chorych rozpoczynających leczenie w ostatnim roku obserwacji (2010 r.) w stosunku do roku poprzedniego (2009 r.). Można założyć, że pewne elementy leczenia tych osób nie zostały zrealizowane do chwili pobrania danych do analiz (listopad 2011 r.). Oznacza to, że jeśli podobne badanie zostałoby wykonane za kilka/kilkanaście miesięcy, ta ostatnia liczba byłaby ponownie wyższa niż jest obecnie.

Średnia wysokość wydatków ponoszonych przez NFZ na leczenie pojedynczej osoby rosła w całym analizowanym okresie i wynosiła od ok. 21 tys. PLN (osoby zaczynające leczenie w 2004 roku) do ok. 35,4 tys. PLN (dla osób z 2009 r.) (ryc. 1). Niższe średnie wydatki na osoby, u których rozpoznano nowotwór w roku 2010, należy powiązać z okresem obserwacji wydatków (patrz: wyjaśnienie jak wyżej). W sumie wydatki NFZ na leczenie chorej rozpoczynającej leczenie w roku 2009 wzrosły o ok. 55\% w stosunku do wydatków 


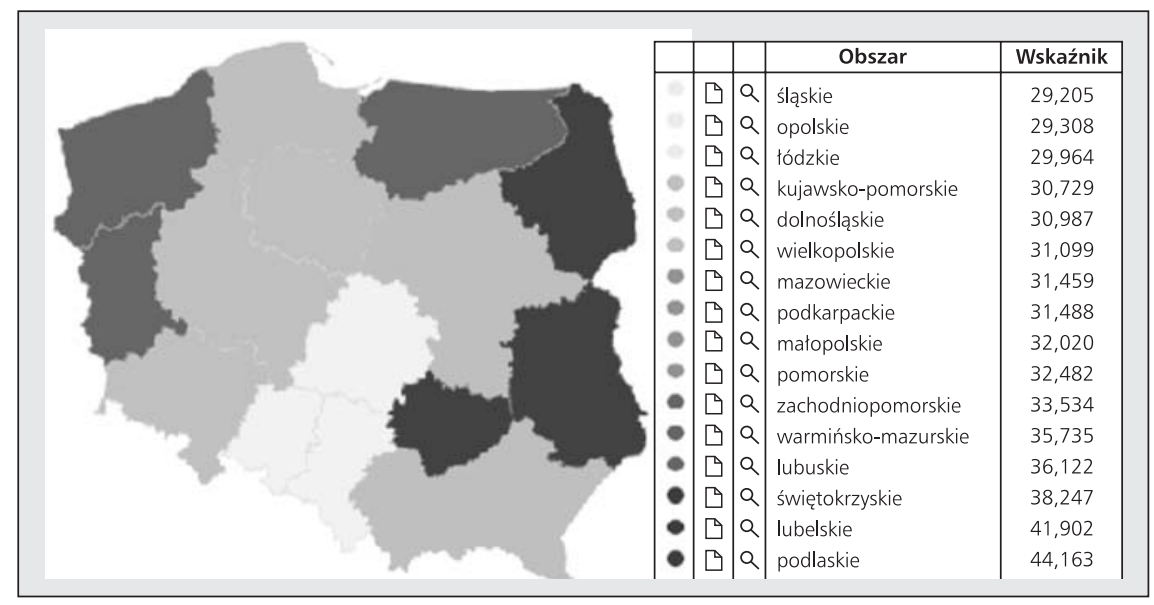

Rycina 2. Międzywojewódzkie różnice w wydatkach NFZ (w PLN) na leczenie chorych, u których w roku 2010 rozpoznano raka piersi. Źródło: obliczenia własne na podstawie danych NFZ

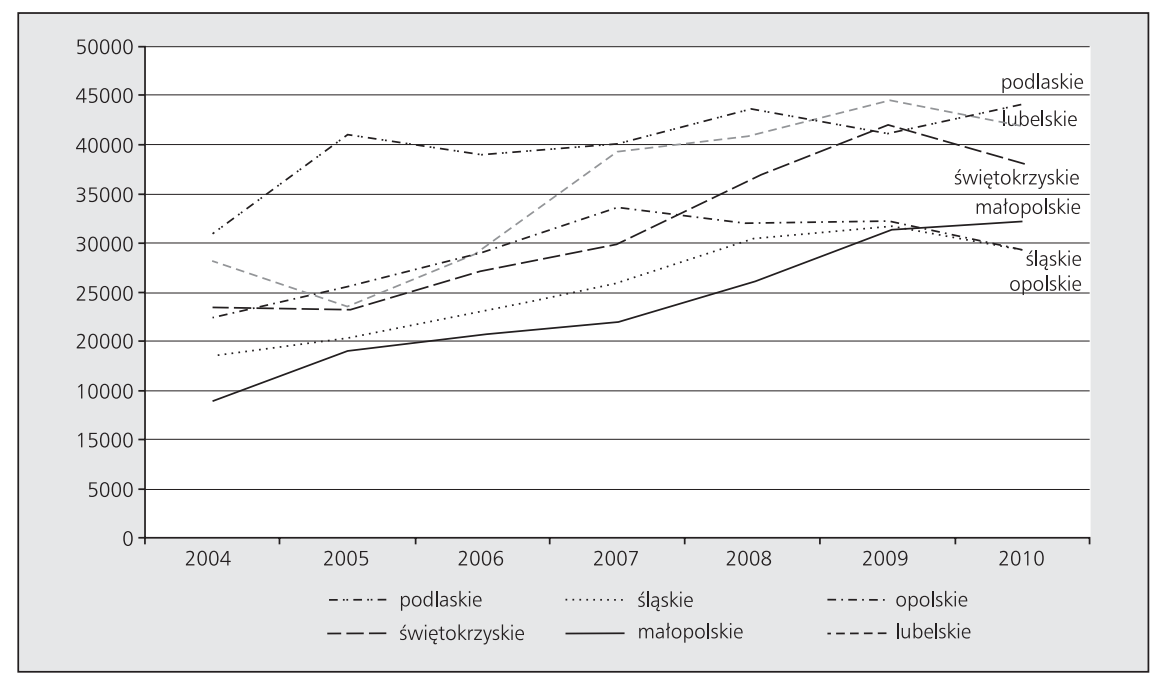

Rycina 3. Zmiany w wydatkach NFZ (w PLN) na leczenie chorych na raka piersi w latach 2004-2010 w wybranych województwach. Źródło: obliczenia własne na podstawie danych NFZ

na chorą z rozpoznaniem ustalonym w roku 2004. W tym czasie stopa inflacji konsumenckiej wzrosła o ok. 17\% [12].

Średnia wysokość wydatków na leczenie chorych na raka piersi różniła się pomiędzy województwami dość znacznie (ryc. 2).W roku 2010 najniższe wydatki (poniżej 30 tys. PLN na osobę) zanotowano w województwach śląskim, opolskim i łódzkim, a najwyższe - w województwach podlaskim i lubelskim (odpowiednio ok. 44 i ok. 42 tys. PLN). W przeciągu analizowanych 6 lat wielkości te zmieniały się, lecz wysokie wydatki w województwie podlaskim, a w mniejszym stopniu lubelskim i warmińsko-mazurskim, utrzymywały się przez większość tego okresu. Leczenie chorych z województwa podlaskiego, w którym rozpoznano raka w 2005 roku, kosztowało średnio 41 tys. PLN, podczas gdy w następnych w kolejności warmińsko-mazurskim i mazowieckim już tylko ok. 26 tys. PLN. Najmniejsze wydatki w tym roku zanotowano w województwie małopolskim (ok. 19 tys. PLN). W roku 2008 najwyższe wydatki na leczenie dotyczyły województw: podlaskiego, warmińsko-mazurskiego i lubelskiego (41-43 tys. PLN), podczas gdy najmniejsze - województwa małopolskiego, wielkopolskiego i dolnośląskiego (ok. 26-28 tys. PLN). W całym analizowanym okresie najniższe wydatki na leczenie chorych na raka piersi zanotowano w województwie małopolskim, a tuż za nimi — dolnośląskim, śląskim, wielkopolskim i kujawsko-pomorskim.

Na rycinie 3 przedstawiono kształt krzywej zmiany wydatków na leczenie raka piersi w latach 2004-2010 dla kilku wybranych województw: podlaskiego, lubelskiego, świętokrzyskiego, małopolskiego, śląskiego i opolskiego. Wykres ten wskazuje, że w większości przypadków znaczny wzrost wydatków zaczął się około roku 2007 i trwał do roku 2009. Charakterystyczne jest, że wydatki w województwie 


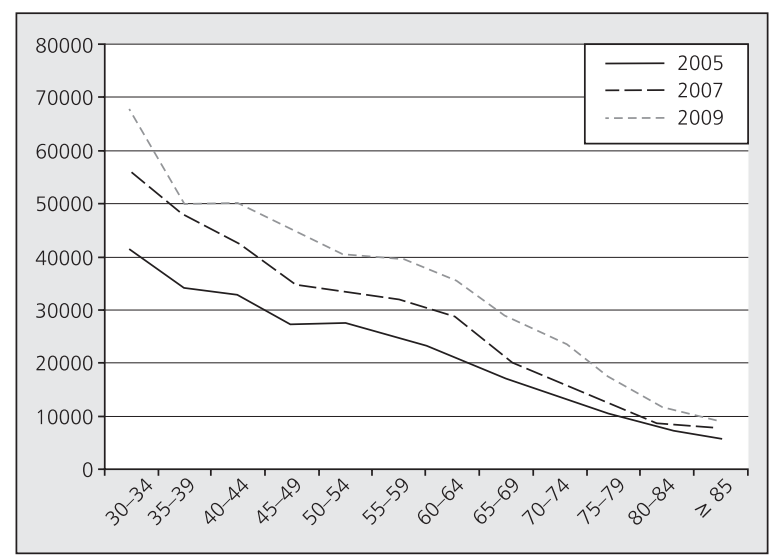

Rycina 4. Wydatki NFZ (w PLN) na leczenie chorych, u których w roku 2009 rozpoznano raka piersi, $z$ uwzględnieniem ich wieku w chwili rozpoznania. Źródło: obliczenia własne na podstawie danych NFZ

podlaskim były zdecydowanie najwyższe od początku okresu obserwacji i niewiele się w tym czasie zmieniały. Z kolei wydatki na leczenie mieszkanek woj. śląskiego, choć także wzrastały w kolejnych latach, pozostawały najniższe, w niektórych latach zmieniając się miejscami z wydatkami na mieszkanki woj. dolnośląskiego i małopolskiego².

We wszystkich województwach wydatki na leczenie chorych na raka piersi zdecydowanie obniżają się wraz z wiekiem (ryc. 4). Pomijając grupy wieku poniżej 30 roku życia (z uwagi na niewielką liczbę chorych na raka piersi w tym wieku), na leczenie chorych w wieku 30-34 lat, u których rozpoznano nowotwór w 2009 roku, wydawano ponad 6 razy więcej niż na leczenie chorych w wieku 85+. Wśród chorych, u których nowotwór rozpoznano w 2005 roku, wartości te wynosiły odpowiednio ok. 41 tys. i 5,9 tys. PLN, a w roku 2007 - 56 tys. i 7,5 tys. PLN. Różnice te mają tendencję do narastania, i to pomimo że naturalny okres obserwacji, a zatem okres ponoszenia potencjalnych wydatków, ulega skróceniu (w przypadku chorych z rozpoznaniem w 2005 r. wynosi on ponad 6 lat, a u chorych z 2009 - tylko 2 lata).

Począwszy od roku 2007, znaczna część chorych na raka piersi w wieku 50-69 lat uczestniczyła w mammograficznych badaniach przesiewowych. W roku 2007, pierwszym roku działania tych programów, wśród chorych leczonych z powodu raka piersi 4181 chorych przeszło badania przesiewowe, natomiast u 4603 chorych badań tych nie wykonywano. W roku 2010 liczba chorych w obu wymienionych grupach wynosiła już odpowiednio 6488 i 2572. Wydatki NFZ na leczenie chorych, u których wykonano w przeszłości badania przesiewowe, były niższe niż na chore, u których takich badań nie wykonano. W roku 2007 różnica ta wynosiła średnio 3193 PLN, a w roku 2010 - 2210 PLN (tab. II). W poszczególnych województwach sytuacja była różna,
Tabela II. Średnie różnice w wydatkach na leczenie jednej chorej na raka piersi, która uczestniczyła w badaniu przesiewowym w porównaniu z wydatkami u chorej, która nie uczestniczyła w takim badaniu, w poszczególnych grupach wiekowych

\begin{tabular}{lcccc}
\hline & 2007 & 2008 & 2009 & 2010 \\
\hline $50-54$ & 1775 & -5462 & -1126 & -2982 \\
$55-59$ & -6717 & -4550 & 552 & -142 \\
$60-64$ & -3889 & -2792 & -1883 & -3140 \\
$65-69$ & -3940 & -3807 & 3291 & -2575 \\
Ogółem & -3193 & -4153 & 209 & -2210 \\
\hline
\end{tabular}

Źródło: obliczenia własne na podstawie danych Narodowego Funduszu Zdrowia

lecz w większości z nich wydatki na leczenie chorych, które przeszły badania przesiewowe, były niższe niż u chorych bez takich badań (ryc. 5). Nieliczne wyjątki, występujące w niektórych latach w województwach lubuskim, podlaskim i kilku innych, nie zmieniają tej podstawowej obserwacji.

\section{Dyskusja}

Wydatki na leczenie są wrażliwym tematem dyskusji publicznej na temat ochrony zdrowia.W dyskusji tej najczęściej przytaczane są całkowite wydatki na zdrowie, ewentualnie z podziałem na ogólne kategorie, takie jak refundacja leków, opieka szpitalna, czy opieka podstawowa. Znacznie rzadziej można poddać analizie wydatki na bardziej szczegółowym poziomie. Przedstawiony materiał dotyczy wydatków na leczenie chorych na raka piersi, oparty na danych zgromadzonych przez NFZ. Źródło to umożliwiło przeprowadzenie analizy obejmującej ok. 104 tys. przypadków, czyli ok. 15 tys. osób rocznie leczonych w latach 2004-2010. [5, 6, 13]. Analizę wykonano, sumując wszystkie wydatki, jakie ponosi NFZ na leczenie chorych z rozpoznaniem raka piersi w ciągu kilku kolejnych lat. Z punktu widzenia metodyki analiz ekonomicznych wydatki te należą do kategorii kosztów bezpośrednich choroby, ale nie obejmują wszystkich tego typu kosztów (brakuje wydatków out-of-pocket) oraz kosztów pośrednich (np. absencji chorobowej).

Sumaryczna kwota wydatków na leczenie chorych na raka piersi w wymienionych latach wyniosła 2,893 mld PLN. Suma wydatków na chore, u których rozpoznano nowotwór w każdym kolejnym roku stopniowo wzrastała, z ok. 324 milionów PLN w roku 2004 do 487 milionów PLN w roku 2010 (tab. I). Należy przy tym pamiętać, że w analizie zastosowano memoriałowe podejście do analizy kosztów, w którym to koszty leczenia przypisywano okresowi (rocznikowi), w którym ustalono rozpoznanie, a nie okresowi realizacji świadczenia. Z tego powodu suma wydatków przypisana danemu rocznikowi była odmienna niż suma wydatków ponoszonych w danym roku (podejście kasowe).

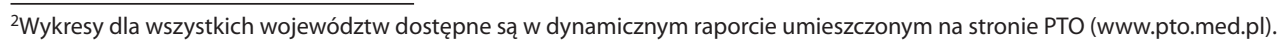




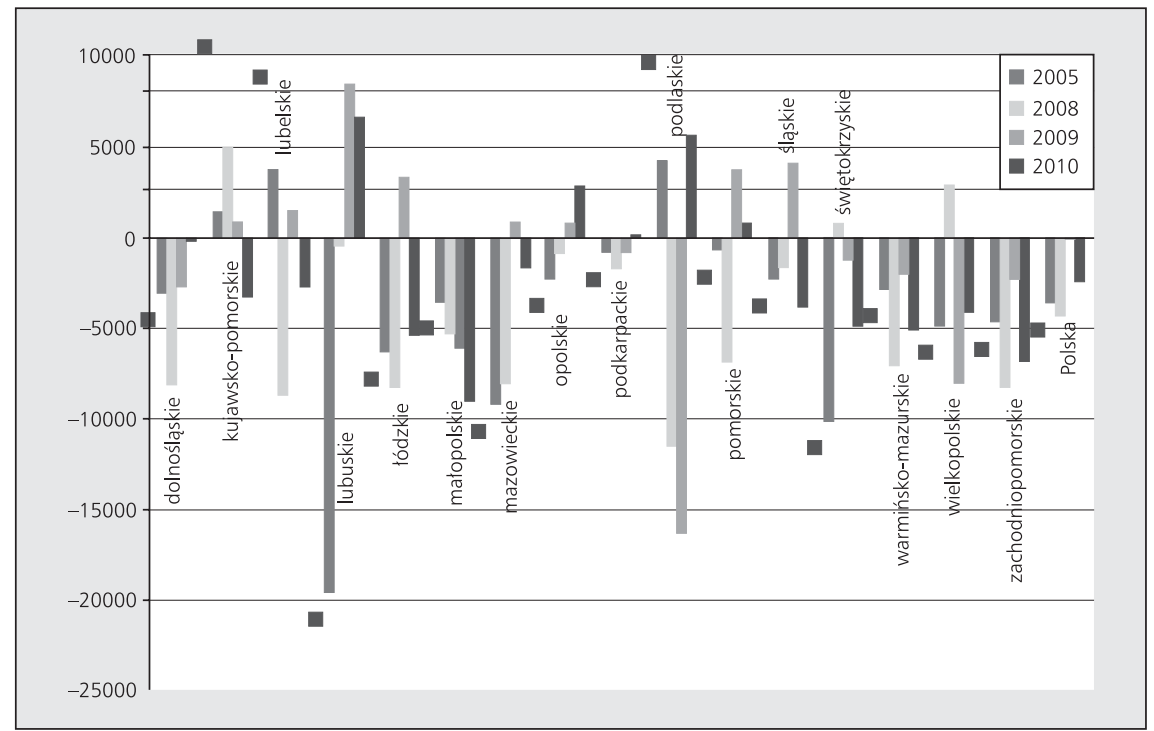

Rycina 5. Średnie różnice w wydatkach na leczenie jednej chorej na raka piersi, która uczestniczyła w badaniu przesiewowym, w porównaniu z wydatkami u chorej, która nie uczestniczyła w takim badaniu, w poszczególnych województwach. Źródło: obliczenia własne na podstawie danych Narodowego Funduszu Zdrowia

Skutek powyższego podejścia można zauważyć m.in. w postaci niewielkiego spadku wydatków na leczenie chorych rozpoczynających terapię w roku 2010 (487 mln PLN) w porównaniu z rokiem 2009 (529 mln PLN). Można przypuszczać, że pewne elementy leczenia chorych, u których rozpoznano raka w 2010 r., nie wystąpiły do chwili pobrania danych do analiz (listopad 2011), bowiem największe wydatki na leczenie raka piersi ponosi się przez 2-3 lata od rozpoznania [5].

Średni poziom wydatków na jedną chorą w ostatnich latach analizy wynosił około 32-35 tys. PLN (ok. 10 tys. USD), co było wielkością 2-5-krotnie niższą od obserwowanych w USA [7, 14]. Wydatki te w roku 2009 wzrosły o ok. 55\% w porównaniu do wydatków z roku 2004. W tym czasie stopa inflacji konsumenckiej wyniosła ok. 17\% [12], co oznacza, że wzrost ten był trzykrotnie szybszy niż stopa inflacji konsumenckiej. Niejasne jest obecnie, jakie czynniki spowodowały ten wzrost; w jakim stopniu wzrost był efektem zmiany cen świadczeń i leków, a w jakim wzrostu liczby świadczeń przypadających na osobę czy zmiany sposobów leczenia (treatment pattern). Zapewne w różnych proporcjach każde z wymienionych czynników odgrywało swoją rolę, lecz zagadnienie to wymaga dalszych analiz.

Interesującym aspektem analizy były różnice w wydatkach na leczenie w poszczególnych województwach. Różnice międzywojewódzkie sięgnęły w roku 2010 ok. 30\% (od 29 tys. do 44 tys. PLN/osobę). Wydatki te były najwyższe w województwach: podlaskim, świętokrzyskim i lubelskim, czyli województwach mniej zurbanizowanych i uważanych za mniej zamożne. Z kolei najniższe wydatki zanotowano w woj. śląskim, uważanym za bardziej zamożne. Różnice między województwami nasiliły się szczególnie w ostatnich kilku latach, począwszy od roku 2007. W woj. podlaskim wydatki na osobę są najwyższe w kraju począwszy od 2005 roku. Ponieważ ceny za poszczególne świadczenia są raczej wyrównane (różnice wynoszą najwyżej kilka procent), różnica prawdopodobnie wynika z rodzaju stosowanych terapii, ich liczby i rodzaju, w tym udziału chorych hospitalizowanych wśród ogółu leczonych [15]. Przyczyny tych różnic stają się tym samym interesującym przyczynkiem do dyskusji na temat efektywności leczenia, w szczególności przy zastosowaniu miernika efektu w postaci 5-letniego przeżycia. Przyczyny różnic w wydatkach można też upatrywać w różnicach w średnim stopniu zaawansowania nowotworu w poszczególnych województwach (leczenie bardziej zaawansowanych przypadków jest z założenia droższe). Analiza tej zależności wymagałaby jednak uzyskania informacji o stadium klinicznym nowotworu.

We wszystkich województwach wydatki na leczenie chorych na raka piersi zdecydowanie obniżają się wraz z wiekiem. Różnice w wydatkach w poszczególnych grupach wiekowych były jeszcze większe niż różnice międzywojewódzkie. W przypadku chorych z roku 2009, różnica między wydatkami na leczenie osoby młodej (30-34 lata) a leczeniem osoby w podeszłym wieku (ponad 85 lat) była prawie 7-krotna (ryc. 4). Zjawisko to nie dotyczy tylko Polski, bowiem sposoby leczenia stosowane u chorych w podeszłym wieku różnią się od tych stosowanych w wieku młodszym [14, 16, 17]. Różnice wynikają głównie ze względów klinicznych (np. większy udział chemioterapii i leczenia celowanego u młodszych chorych), choć nie można także wykluczyć przyczyn społecznych: mniej agresywnego leczenia osób w wieku podeszłym. 
W przypadku niniejszej analizy dodatkowym powodem tych różnic może być rodzaj obserwacji. Ponieważ do wydatków na rzecz danej osoby wliczano terapie niezależnie od tego, kiedy je zastosowano, naturalne jest, że osoby przeżywające dłużej uzyskiwały więcej świadczeń. W przypadku osób w podeszłym wieku naturalne zgony (niekoniecznie związane z rakiem piersi) mogą powodować, że obserwacja dotyczyła krótszego okresu i powodowała niższe sumaryczne wydatki. Istotne jest, że wraz z upływem czasu wymienione różnice wzrastały od pięciokrotnych w roku 2005 do sześciokrotnych w 2007. Zmiana ta i jej tempo są bardzo znamienne, biorąc pod uwagę krótki, 5-letni okres analizy.

Wprowadzenie w grupie wiekowej 50-69 lat szerokich, choć jeszcze nie powszechnych, badań przesiewowych, spowodowało znaczne zmiany w obrazie wydatków na leczenie. Przede wszystkim w grupie chorych leczonych $z$ powodu raka piersi $w$ tym przedziale wiekowym już ok. 2/3 stanowią kobiety, które przebyły badanie przesiewowe. Nie oznacza to, że leczony nowotwór został w tym badaniu wykryty, lecz uprawdopodabnia taki scenariusz. Jednocześnie wydatki NFZ na leczenie chorych, które poddano badaniom przesiewowym, były w większości roczników niższe o kilka tysięcy złotych (3193 PLN w roku 2007, 4153 PLN w 2008 i 2210 PLN w roku 2010; tab. II), co stanowi od $8 \%$ do $15 \%$ całkowitych kosztów leczenia. Mimo że w niektórych województwach obraz ten nie jest tak oczywisty (ryc. 5), można uznać, że jest to pośredni dowód obniżenia kosztów leczenia w przypadku wczesnego wykrycia nowotworu w badaniach przesiewowych.

\section{Wnioski}

Niniejsza analiza jest jedną z pierwszych analiz kosztów leczenia raka piersi w Polsce. Została ona przeprowadzona z wykorzystaniem zasobów informacyjnym NFZ, który od wielu lat gromadzi dane na temat rozliczanych świadczeń, a od kilku lat jest także przygotowany do przeprowadzania analiz na ich podstawie. Analiza pozwoliła na określenie podstawowych wielkości koniecznych do zarządzania systemem zwalczania raka piersi: sumarycznej wysokości nakładów na leczenie raka piersi na rok, średniej wysokości nakładów na jedną chorą, wysokości wydatków ponoszonych w poszczególnych województwach czy w poszczególnych grupach wiekowych.

Wyniki analizy wskazują, że przy względnie stałej liczbie chorych na raka piersi wydatki na ich leczenie szybko rosną, przekraczając poziom wzrostu inflacji. Przyczyna istotnych różnic wydatków pomiędzy poszczególnymi województwami czy grupami chorych tylko częściowo znajduje wyjaśnienie i powinna być przedmiotem dalszych analiz. Analizy te powinny w szczególności uwzględnić ewentualne różnice w praktyce postępowania (treatment pattern) w poszczególnych ośrodkach leczenia raka piersi w kraju.
Polityka zdrowotna państwa nie musi wymuszać ujednolicenia wydatków na leczenie raka piersi u wszystkich chorych; bez względu na miejsce zamieszkania czy wiek. Ważne jest jednak, żeby mieć świadomość różnic w wydatkach i znać ich przyczyny. Powinno to prowadzić do optymalizacji procesów leczenia i poszukiwania najbardziej efektywnych sposobów zarządzania tym procesem, a jednocześnie zarządzania środkami przeznaczonymi na leczenie.

Biorąc pod uwagę społeczną wagę problemu oraz skalę wydatków (ok. 500 mln PLN rocznie), wydaje się zasadne poświęcenie większej uwagi możliwościom poprawy wyników leczenia raka piersi przy posiadanych zasobach. Wykorzystanie możliwości analitycznych tkwiących w danych gromadzonych przez NFZ może ułatwić podejmowanie świadomych i celowych decyzji z zakresu polityki zdrowotnej i organizacji systemu ochrony zdrowia. W szczególności warto rozważyć powierzenie większych kompetencji oraz odpowiedzialności za proces leczenia wyselekcjonowanym i przygotowanym do tego placówkom. Dysponowanie informacjami na temat przebiegu i wydatków na leczenie powoduje, że zarządzanie systemem staje się bardziej bezpieczne dla obu stron: płatnika i wykonawców usług zdrowotnych.

\section{Dr n. med. Adam Kozierkiewicz}

Europejski Bank Inwestycyjny, JASPERS

e-mail:akozierkiewicz@wp.pl

Otrzymano: 12 grudnia $2012 \mathrm{r}$.

Przyjęto do druku: 3 stycznia 2013 r.

\section{Piśmiennictwo}

1. WHO. The world health report: health systems financing: the path to universal coverage. Geneva: World Health Organization, 2010.

2. WHO. The Tallinn Charter: Health Systems for Health and Wealth, WHO European Ministerial Conference on Health Systems. Tallinn, Estonia, 2008.

3. OECD. More Value for Money in Health. Paris: OECD, 2010.

4. Kozierkiewicz A, BochenekT, Gilewski D i wsp. Biała Księga, Zwalczanie raka jelita grubego i raka piersi w Polsce na tle wybranych krajów europejskich. Warszawa-Kraków: Ośrodek Analiz Uniwersyteckich Sp. z o.o., 2011.

5. Legorreta AP, Brooks RJ, Leibowitz AN, Solin LJ. Cost of breast cancer treatment. A 4-year longitudinal study. Arch Intern Med 1996; 156: 2197-2201.

6. Fu AZ, Jhaveri M. Healthcare cost attributable to recently-diagnosed breast cancer in a privately-insured population in the United States, J Med Econ 2012; [Epub ahead of print].

7. Radice $D$, Redaelli A. Breast cancer management: quality-of-life and cost considerations, Pharmacoeconomics 2003; 21: 383-396.

8. Ustawa z dnia 27.08.2004 r. o świadczeniach opieki zdrowotnej finansowanych ze środków publicznych (z późn. zm.). Dz.U. (2008) Nr 164: p. poz. 1027.

9. Minister Zdrowia, Rozporządzenie Ministra Zdrowia z dnia 11.01.2010 r. zmieniające rozporządzenie w sprawie świadczeń gwarantowanych z zakresu programów zdrowotnych (z późn. zm.), Dz. U., p. p. poz. 29., Nr 05: 2010.

10. Rozporządzenie Ministra Zdrowia z dnia 27 czerwca 2006 r. w sprawie zakresu niezbędnych informacji gromadzonych przez świadczeniodawców (...) (Dz.U.06.114.780).

11. World Health Organization, Międzynarodowa Statystyczna Klasyfikacja Chorób i Problemów Zdrowotnych, Rewizja Dziesiąta, Kraków: Fundacja Zdrowia Publicznego, 1992. 
12. Główny Urząd Statystyczny, Zharmonizowane wskaźniki cen konsumpcyjnych (HICP), 2012. [Online]. Available: (http://www.stat.gov. pl/gus/5840_5582_PLK_HTML.htm. [Data uzyskania dostępu: 1701 2012].

13. D. B. B. H. Bradley CJ, Insurance and inpatient care: differences in length of stay and costs between surgically treated cancer patients. Cancer 2012; [Epub ahead of print].

14. Yabroff KR, Lamont EB, Mariotto A i wsp. Cost of care for elderly cancer patients in the United States. J Nat/ Cancer Inst. 2008; 100: 630-641.
15. Kozierkiewicz A, Śliwczyński A, Jassem J, Topór-Mądry R, Paszkiewicz J. Praktyka leczenia raka piersi w Polsce. Nowotwory J Oncol 2012; 62: 250-262.

16. Hurria A, Leung D, Trainor K i wsp. Factors influencing treatment patterns of breast cancer patients age 75 and older. Crit Rev Oncol Hematol 2003; 46: 121-126.

17. Debled M, Madranges N, Mertens C i wsp. First-line chemotherapy for metastatic breast cancer in patients $\geq 75$ years: A retrospective single-centre analysis. Crit Rev Oncol Hematol 2011; 80: 171-179. 